\title{
Evaluating User Experience of Using Cerdik BM Series 1 Interactive Pedagogical Tool
}

\section{Nurulwahida Azid}

Assoc. Prof., School of Education \& Modern Languages, Universiti Utara Malaysia, Malaysia,nurulwahida@uum.edu.my

\section{Nuraini Yusoff}

School of Languages, Civilisation, and Philosophy, Universiti Utara Malaysia, Malaysia,nuraini@uum.edu.my

\section{Rafizah Rawian}

School of Languages, Civilisation, and Philosophy, Universiti Utara Malaysia, Malaysia,rafizah@uum.edu.my

\section{Nuryazida Sabarudin}

School of Education \& Modern Languages, Universiti Utara Malaysia, Malaysia, nygdah@gmail.com

\section{Mohd Zaini Ishak}

Sek Keb Batu Lima, Sik, Malaysia, ishakmohdzaini@gmail.com

In this study, an interactive pedagogical tool - Cerdik BM Series 1 was created using the Adobe Flash CS6 Software. This tool was developed to assist students' difficulties in Malay Language literacy skills as one of the ways to support the Literacy and Numeracy Screening (LINUS) programme. This application highlighted the importance of multiple intelligences and fun learning environment. A questionnaire and two sets of rubrics, both already evaluated on the design and application of Cerdik BM Series 1 were used in this study. Feedbacks from experts, students and teachers were gathered and analyzed. The findings revealed high experts' evaluation consensus values of Cerdik BM Series 1 in terms of its design and curriculum that comprised of three Malay Language's constructs namely Construct 1 - vowel and consonant letters, Construct 2 - cite syllable and Construct 3 - cite two combined syllables, read and write open syllables). It was discovered that the reliability scores for Cerdik BM Series 1 were between 0.87 and 0.97 .

Keywords: LINUS, Malay language, fun learning, multiple intelligences, game-based learning

Citation: Azid, N., Yusoff, N., Rawian, R., Sabarudin, N., \& Ishak, M. Z. (2020). Evaluating User Experience of Using Cerdik BM Series 1 Interactive Pedagogical Tool. International Journal of Instruction, 13(4), 409-426. https://doi.org/10.29333/iji.2020.13426a 


\section{INTRODUCTION}

The Literacy and Numeracy Screening (LINUS) programme is one of the initiatives by the Malaysian Education National Key Result Area (NKRA) to ensure every child in Malaysia possesses a good mastery of basic literacy and numeracy skills after undergoing three years of mainstream primary education (Peng, 2015). Each child is envisaged to be able to read, write and understand words, simple and complex sentences in Bahasa Melayu (the official language) and later apply such knowledge in learning and regular correspondence (Peng, 2015). A child is likewise expected to be competent in reading, writing, counting and arranging whole numbers and to be capable to apply mathematical skills and to solve basic mathematical operations. Data Literacy and Numeracy Screening (LINUS) revealed that in 2008, 105,255 (23\%) from 463,990 Malaysian students failed to master reading fluency (Peng, 2015). Hence, effective measure is necessary to remedy such problem.

This study only focused on students who enrolled in LINUS Bahasa Melayu (Malay Language) remedial class. The remedial students in this class were those who required some extra guidance to improve their reading and writing skills. Although the number of the remedial students was small, each student had different levels of language skills and demanded teachers to be more creative in planning lessons and producing teaching aids. Using interactive tools in the classroom was one of the ways to facilitate these students. Li (2016) stated that the use of multimedia-based teaching aids could attract students' attention. Chun-hui and $\mathrm{Fu}$ (2015) discovered that students who were assisted by animated materials obtained tremendous achievement and majority of these students insisted on more creative and innovative teaching and learning methods. According to Wang (2018), encompassing videos, pictures and audio in teaching methods would create a relaxed and fun learning atmosphere. In addition, the use of interactive and entertaining teaching materials such as interactive games could increase students' engagement and achievement (Huizenga, Dam, Voogt \& Admiraal, 2017). Hence, the objective of this study was to develop Cerdik BM Series 1 - an interactive application to assist students in the Malay Language remedial classes. Its main aim was to aid these students to strengthen their reading and writing skills.

\section{Language Literacy: The Global Learning Crisis}

A decade ago a significant investment was made in the effort to increase children's access to education (UNICEF, 2018). Based on the Sustainable Development Goal 4 target, UNICEF is committed to ensuring that by 2030 all boys and girls have access to quality early childhood education (UNICEF, 2018). According to the United Nation under the Sustainable Development Goals, more than 265 million children had left schooling and 22\% of them were pre-schoolers (United Nation, 2019). Meanwhile, 617 million children and adolescents worldwide lacked literacy skills. Therefore, World Vision and Save the Children have worked together to improve the quality of early childhood education through a literacy program to improve children's reading skills (UNICEF, 2018). In line with the objectives of UNICEF to reduce the number of dropout among children, the Ministry of Education (MOE) in Malaysia has introduced Special Education in 1997 to overcome the Malay Language literacy among slow 
learners (Abdul Wahid \& Samsudin, 2017). The Literacy and Numeracy Screening (LINUS) is a program aimed at ensuring that all children in Malaysia can master basic literacy and numeracy skills over three years of mainstream primary education. The LINUS program focuses on early intervention before children enter Year Four. Malay Language Literacy was the focus of this study because without mastering Malay literacy skills (Native Language) then the child will be left behind during class activities. Besides Malaysia, other country such as Nigeria is also going through the same dilemma, hence, a study entitled Empowering Primary School Pupils through Literacy Remediation Project conducted in Uyo Local Government Area for 72 children was also aimed at reducing the decline in reading skills (Udofia, Ekukinam\& Akpan, 2010). Meanwhile, a study on improving language literacy among low-achieving children in learning has also been conducted in Sri Lanka, involving 97 third- and fourth-grade children at four schools in Mannar, a district in Sri Lanka (Selvarajan \& Vasanthagumar, 2012). The focus of the study conducted in several countries was targeting to improve children's literacy skills so as to reduce the number of school dropouts. Findings conducted in several countries have revealed that teaching techniques, tools and activities provided by teachers can help children master language literacy faster (Abdul Wahid \& Samsudin, 2017; Selvarajan \& Vasanthagumar, 2012; Udofia, Ekukinam \& Akpan, 2010). This finding clearly showed that an interactive pedagogical tool could be one alternative to accelerate the learning process of children to master the Malay Language and on this basis enhanced Cerdik BM Series 1 was developed so that no child will be left behind among children in Malaysia which coincides with the goal of global education (UNICEF, 2018).

This study was deemed significant because according to Miswan and Mohd Adnan (2017) there were two problems in the development of interactive applications to aid children's literacy namely, the development of applications that (i) focused only on animation and graphic features rather than educational materials and (ii) were presented in a stereotyped and boring way. Therefore, in this study Cerdik BM Series 1 was built on constructive alignment models that give special emphasis to the content of lessons to be delivered based on measurable learning outcomes, learning content, learning activities that apply game based learning theory and interactive assessment. Meanwhile the Cerdik BM Series 1 not only emphasized graphics and animation but also celebrated children's multiple intelligences by integrating 8 multiple intelligences within each Cerdik BM Series 1 interface. Meanwhile the Cerdik BM Series 1 not only emphasized on graphics and animation but also celebrated children's multiple intelligences by integrating 8 multiple intelligences within each Cerdik BM Series 1 interface. This was in contrast to the existing application of LINUS literacy application built in the study of Miswan and Mohd Adnan (2017) using the concept of storytelling irrespective of the aspect of the multiple intelligences of LINUS students. In fact, application X (not the real name) was built on one and two construct compared to Cerdik BM Series 1 which covered construct 1 until 3 (Construct 1 - vowel and consonant letters, Construct 2 - cite syllable and Construct 3 - cite two combined syllables, read and write open syllables) for student education as young as 4 to 10 years old. In addition, the existing app just like $\mathrm{X}$ was a complete education for 5-7 year old. Additionally, the Cerdik BM Series 1 
construction technique used the combination of photoshop, illustrator and flash. The benefit of using the combination of photoshop, illustrator and flash was that it could modify the pictures, produced clear, attractive and sharp vectors and the flash produced animation that was more interactive and able to play formatted videos. Besides, according to Maswan and Mohd Adnan (2017) the development of LINUS interactive application in their study which also used photoshop found the weakness that the photoshop bitmap broke when users zoomed on the image. Meanwhile the animation was less interactive because of the use of plug in kwisher in photoshop compared to the combination of photoshop, illustrator and flash.

\section{Multiple Intelligences: Application of Theory into Practice}

Intelligence is needed to experience a better life. Therefore, it is crucial to enrich students' multiple types of intelligences rather than just focusing on verbal linguistic intelligence and mathematical logic (Ajam \& Hemmatipoor, 2018). Giving too much emphasis on these two intelligences could restrict the chances to learn through other intelligences such as visual spatial, kinestatics, music, interpersonal, intrapersonal and naturalists (Hanafin, 2014). Gardner's multiple intelligence theory refers multiple intelligences as "different ways of learning" (Ajam \& Hemmatipoor, 2018). The application of eight different types of intelligences in learning could upsurge students' understanding, curiosity, competence and self-esteem (Williams, 2007). Table 1 shows a summary of the application of various intelligence theories in the Cerdik BM Series 1.

Table 1

Application of Multiple Intelligences in Cerdik BM Series 1

\begin{tabular}{ll}
$\begin{array}{l}\text { Multiple } \\
\text { Intelligences }\end{array}$ & Example of application in Cerdik BM Series 1 \\
\hline $\begin{array}{l}\text { Verbal } \\
\text { Linguistics }\end{array}$ & $\begin{array}{l}\text { Cerdik BM Series 1 focuses on teaching and learning vowels, consonants and } \\
\text { syllables. Voice-activated instructions are used to facilitate students in the } \\
\text { LINUS program to understand the given instructions. }\end{array}$ \\
\hline $\begin{array}{l}\text { Mathematical } \\
\text { Logic }\end{array}$ & $\begin{array}{l}\text { Cerdik BM Series 1 uses scores for correct responses. The content of the } \\
\text { lesson, learning activities and assessment of each construct are logically } \\
\text { arranged based on the degree of difficulty and stages in Bloom Taxonomy. }\end{array}$ \\
\hline Visual Spatial & $\begin{array}{l}\text { Cerdik BM Series 1 uses image application, 3D object, interesting color and } \\
\text { graphic animation. }\end{array}$ \\
\hline Kinestatic & $\begin{array}{l}\text { Cerdik BM Series 1 uses animation, object movements such as the roller } \\
\text { coaster and 3D graphics of star movements as well as explosion of balloons. }\end{array}$ \\
\hline Music & $\begin{array}{l}\text { Cerdik BM Series 1 uses songs, music and sound effects such as the cheering } \\
\text { for each correct answer. }\end{array}$ \\
\hline Interpersonal & $\begin{array}{l}\text { Cerdik BM Series 1 uses a storyboard that includes multiple characters with } \\
\text { various interpersonal skills. }\end{array}$ \\
\hline Intrapersonal & $\begin{array}{l}\text { Cerdik BM Series 1 uses a storyboard that incorporates intrapersonal skills that } \\
\text { depict characters' feelings and belongings. }\end{array}$ \\
\hline Naturalist & $\begin{array}{l}\text { Cerdik BM Series 1 incorporates animal graphics, fruits, sound of water and } \\
\text { garden surroundings. }\end{array}$ \\
\hline
\end{tabular}

The Concept of Multimedia in Game-Based Learning 
The compelling use of technology in education has changed the essence of instruction and the ongoing progressions in instructive advancements have yielded positive outcomes in the education area. This new educational innovation is supporting both educating and learning forms. Innovations have digitized classrooms through advanced learning apparatuses like PCs, iPads, cell phones, shrewd computerized white sheets. These revolutionized classrooms have extended course contributions and also expanded students' commitment and inspiration towards learning.

Digitalized education sector has led to the rapid growth of multimedia classrooms. According to Rajendra and Sudana (2018), multimedia has been integrated into learning when conventional teaching (chalk \& talk) methods are no longer effective in stimulating the learning process. Multimedia refers to the combination of various media elements to a specific tool that bring results to users. Among the multimedia elements that are often used to produce an application are texts, pictures, graphics, animation, sound and videos (Gunawardhana \& Palaniappan, 2016; Salleh, Ghazali \& Nor, 2017; Wiana, 2018). Multimedia applications that generate simulation, animation and visuals can significantly assist students to extract abstract information, to make connections between verbal and visual representations of content as well as to identify and solve problems more easily (Wiana, 2018).

Multimedia applications have led to the creation of many latest pedagogical tools and the virtual game-based learning. Law and Chen (2016) asserted that virtual game-based learning could help students to understand conceptual knowledge and provide clear guidance to improve the effectiveness of learning. Various studies had also concluded that virtual game-based learning could enhance students' motivation, knowledge and cognitive skills (Gunawardhana \& Palaniappan, 2016; Huizenga et al., 2017; Rajendra \& Sudana, 2018; Wiana, 2018).

\section{The Conceptualisation of Cerdik BM Series 1}

Cerdik BM Series 1 was an interactive application that was developed using flash software with a combination of five multimedia elements, namely text, graphics, animation, audio and video. This pedagogical tool was especially designed for students who did not master the LINUS (Literacy and Numeracy Programs) constructs in listening, speaking, and writing skills in the Malay Language. In addition, this application was also suitable for preparing pre-school children for entering Year One in primary schools.

The curriculum of Cerdik BM Series 1 was based on a constructive alignment model in which each learning outcome would be attained through a continuous process that ranges from learning outcomes, lesson contents, learning activities and assessments. The curriculum of Cerdik BM Series 1 was operationally defined as three Malay Language's constructs (Construct 1 - vowel and consonant letters, Construct 2 - cite syllable and Construct 3 - cite two combined syllables, read and write open syllables) hence it should not be referred to as a program.

The content of the lesson, learning activities and assessments were formed based on interactive games that were rooted from the concept of fun-learning environment. The 
fun learning environment is crucial since it can help to develop students' physical, socio-psychological, cognitive, language and potential (Ministry of Education, 2013). In addition, the fun learning concept could also create a more relaxed and exciting learning atmosphere.

The element of fun learning was featured through its "entertaining and rewarding" learning activities. Each learning activity used colorful and interesting animation where cartoon figurines and pop-up achievement scores were used. Motivating words like "try again", "congratulations you have succeeded" and "marvelous" were also used in each learning activity. Additionally, voice-activated learning instruction system was also featured in this tool. Its main purpose was to ensure that students would be able to understand the given instructions easily and clearly. Through this application, students would be able to master three Malay Language's constructs namely Construct 1 (vowel and consonant letters), Construct 2 (cite syllable) and Construct 3 (cite two combined syllables, read and write open syllables).

\section{Research Questions}

This study was carried out based on the following research questions:

1. What are the reliability values for Cerdik BM Series 1 based on its design and curriculum (Construct 1 - vowel and consonant letters, Construct 2 - cite syllable and Construct 3 - cite two combined syllables, read and write open syllables)?

2. What is the agreement value for the average measure of intra-class correlation coefficient (ICC) among the panel of experts after assessing Cerdik BM Series 1?

3. What is the descriptive analysis of students' assessment rubric for Cerdik BM Series $1 ?$

4. What are the students' and teachers' evaluation score for Cerdik BM Series 1 ?

5. What are the experts' views about the Cerdik BM Series 1?

\section{METHOD}

\section{Research Design}

This study adapted mixed-method approach (Creswell, 2014). Quantitative research was used to examine students', teachers' and experts' assessments towards Cerdik BM Series 1. Qualitative research, on the other hand, was used to gauge experts' views about the Cerdik BM Series 1.

\section{Instruments}

A questionnaire and two sets of rubrics were used to evaluate the design and application of Cerdik BM Series 1 . The questionnaire (Reliability $=.80$ ) which was modified and adapted from Danakorn (2011) was distributed to a panel of experts while the set of rubrics (Reliability $=.78$ ) and its scoring which were modified and adapted from Schrock (2018) was disseminated to students and teachers. 
Interview protocols were used to examine the experts' views about the interactive application of Cerdik BM Series 1. The interview protocol had undergone through the validity and reliability processes to ensure its validity. A total of five qualitative experts had been appointed (1) to review the interview protocols in order to certify their appropriateness and (2) to examine the language use of the interview protocols in order to ascertain its suitability and clarity. Each interview session was about 20 to 30 minutes and the conversations were recorded with the respondents' permission.

\section{Sample and Procedure}

This study had chosen eight academicians from Universiti Utara Malaysia, a specialist from the Malay Language Literacy Unit (FasiLINUS), a special remedial officer, six teachers and two groups of students from the LINUS program from two national schools in Kota Setar (a town) and Sik (a rural area) districts.

The eight academicians were appointed as assessors. They were lecturers from public institutions of higher learning who are the experts in the Malay Language, assessment and measurement, curriculum, education management, moral education and mathematics. All assessors had experience of teaching and conducting research of more than ten years. The evaluation process took effect simultaneously for five hours. During the assessment session, all assessors, students and teachers were given the opportunity to try Cerdik BM Series 1 interactive application to experience the learning process themselves.

30 Primary level 1 students aged between 7 and 9 years and six teachers with special education teaching experience of more than seven years were selected as the respondents.

In evaluating the design of Cerdik BM Series 1, respondents were to score its clarity of the information and interaction as well as its presentation layout. In evaluating its curriculum, respondents had to assess its learning outcomes, lesson contents, learning activities and assessments.

A purposive sample selection design was used in this study. Its samples were chosen based on their background and the purpose of this study to ensure that the data obtained could give meaning to the results of the study (Creswell, 2014).

\section{Reliability}

Besides the Intra-class Correlation Coefficient analysis, this study also aimed to achieve the reliability values of Cerdik BM Series 1 based on its design - information, interaction and presentation and its curriculum (comprises of three main constructs Construct 1 - vowel and consonant letters, Construct 2 - cite syllable and Construct 3 cite two combined syllables, read and write open syllables) and also Creswell (2014) suggested that the reliability index in a test was categorized as satisfactory if it is worth about 0.7. According to Pallant (2001), the alpha index value of 0.7 and above was good for instruments scale that had ten or more items. 


\section{Data Analysis Techniques}

Quantitative findings were analyzed using descriptive analysis, reliability analysis of Cronbach Alpha and Intra-class Correlation Coefficient (ICC) to see the agreement of all assessors on the application's assessment criteria. ICC was an inter-rater reliability used to obtain agreement value between assessors (Landers, 2019). The ICC relationship was a significant estimation of the reliability of quantitative data (Landers, 2019), while qualitative data was analyzed using content analysis. The data analysis process was carried out in three phases, namely transcription, data reduction and coding (Creswell, 2014).

Table 2

Rubrics for Assessing the Use of Cerdik BM Series 1 (Descriptive Analysis)

\begin{tabular}{ll}
\hline Description & Score \\
\hline Excellent & 4 \\
Good & 3 \\
Average & 2 \\
Needs improvement & 1 \\
Weak & 0 \\
\hline
\end{tabular}

Table 3

Rubrics for Assessing the Design and Application of Cerdik BM Series 1

\begin{tabular}{ll}
\hline Level & Score \\
\hline Excellent & $20-17$ \\
Good & $16-13$ \\
Average & $2-10$ \\
Needs improvement & $9-6$ \\
Weak & $5-0$ \\
\hline
\end{tabular}

\section{FINDINGS}

The findings of the study were reported and discussed quantitatively and qualitatively.

\section{Quantitative Findings}

Table 4 showed the reliability value of the first evaluation criteria - the information design. In this criterion, content of the application, language of presentation (it should be easily understood), integration of various intelligence theories, integration of thinking skills elements, lesson content (that are linked to students' everyday life) and integration of fun learning were analyzed. The reliability values for all components of the design were high. The reliability score for information design was .87 while the interaction design was .92 . The reliability score for presentation design was .96 while .97 was the score for the curriculum of Cerdik BM Series 1. 
Table 4

Reliability Values for the Design and Curriculum of Cerdik BM Series 1

\begin{tabular}{lll}
\hline Criteria & N (Item) & Cronbach's Alpha \\
\hline Information Design (Information Clarity) & 7 & .87 \\
Interaction Design (User friendly) & 9 & .92 \\
Presentation Design (Presentation Layout) & 20 & .96 \\
Curriculum (Three Malay Language's constructs) & 20 & .97 \\
\hline
\end{tabular}

Table 5 displayed the experts' evaluation consensus values of Cerdik BM Series 1. The average ICC score for information design was .872 with confidence interval of $95 \%$ from .667 to .97 ( F ( $7,42=7.829, \mathrm{p}<0.000)$, the interaction design obtained .924 with confidence interval of $95 \%$ from .807 to .982 (F $(7,56=13.082$, p < 0.000$)$, average ICC score for presentation design was .956 with the confidence interval of $95 \%$ from .895 to $.99(\mathrm{~F}(7,133=22,749, \mathrm{p}<0,000)$, and as for curriculum, its average ICC score was .972 with a $95 \%$ confidence interval of .934 to $.993(\mathrm{~F}(7,133=36.121, \mathrm{p}<0.000)$.

Table 5

Intra-class Correlation Coefficient (ICC) Value based on the Design and Curriculum of Cerdik BM Series 1

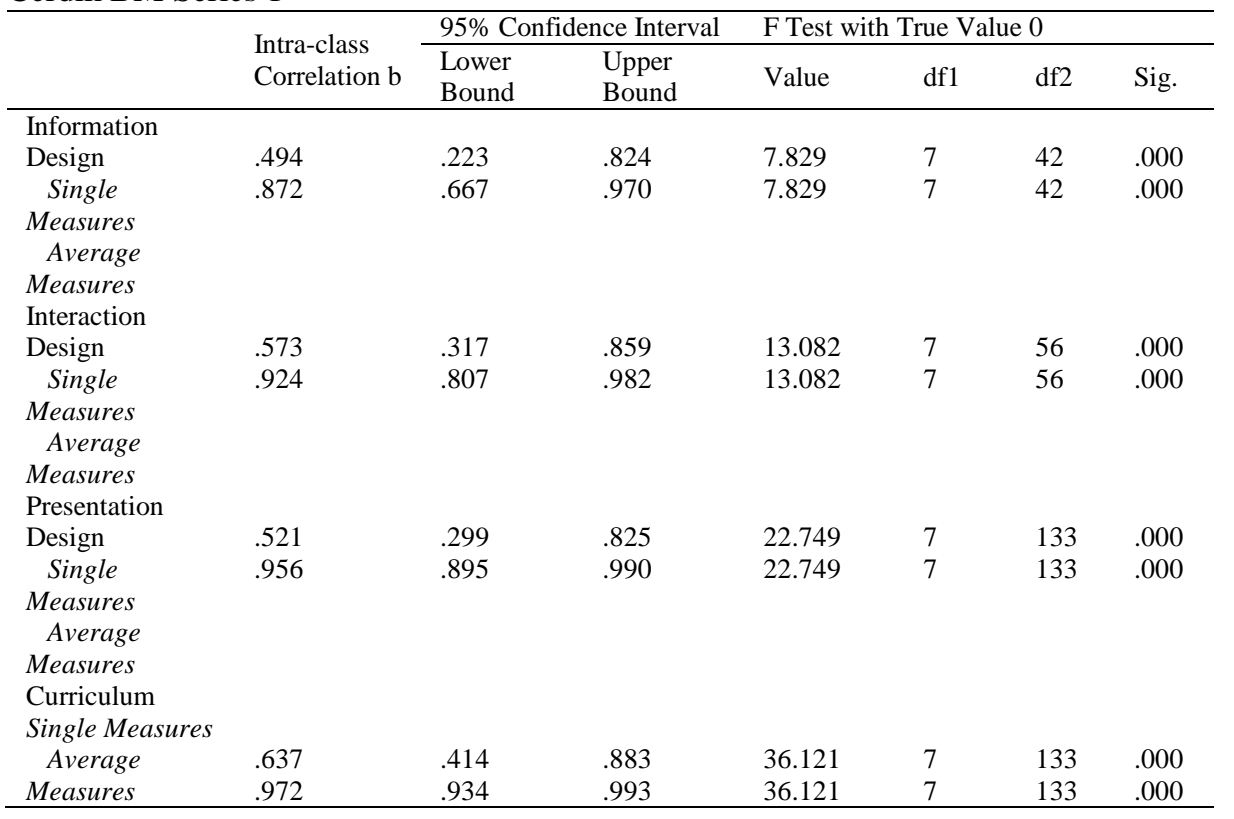

Table 6 illustrated the students' feedbacks on Cerdik BM Series 1 interactive application. $50 \%$ of the students $(n=15)$ had given a score of 4 and $50 \%(n=15)$ had given a score of 3 on the interface and sound of the application. In terms of engagement or motivation, $14(47 \%)$ students had given a score of 4 and $16(53 \%)$ had given a score of 3. For user friendly criteria, 53\% $(n=16)$ had given a score of 4 and another 14 $(47 \%)$ had given a score of 3 . As for the achievement criteria or easy to use, $87 \%(\mathrm{n}=$ 
26) had given a score of 3 while the remaining 13\% $(n=4)$ had given a score of 4 . Furthermore, for the differences in the learning session criteria, $70 \%$ of the students had given a score of 3 while $23 \%$ had given a score of 4 and the remaining $7 \%$ had given a score of 2.

Table 6

Students' Feedbacks on the use of Cerdik BM Series 1 Interactive Application

\begin{tabular}{|c|c|c|c|c|c|c|c|c|c|c|}
\hline \multirow{2}{*}{$\begin{array}{l}\text { Criteria/ } \\
\text { Score }\end{array}$} & \multicolumn{2}{|c|}{4} & \multicolumn{2}{|c|}{3} & \multicolumn{2}{|c|}{2} & \multicolumn{2}{|c|}{1} & \multicolumn{2}{|c|}{0} \\
\hline & $f$ & $\%$ & $\bar{f}$ & $\%$ & $\bar{f}$ & $\%$ & $f$ & $\%$ & $\bar{f}$ & $\%$ \\
\hline $\begin{array}{l}\text { Interface and } \\
\text { sound }\end{array}$ & 15 & 50 & 15 & 50 & 0 & 0 & 0 & 0 & 0 & 0 \\
\hline $\begin{array}{l}\text { Engagement/ } \\
\text { motivation }\end{array}$ & 14 & 47 & 16 & 53 & 0 & 0 & 0 & 0 & 0 & 0 \\
\hline $\begin{array}{l}\text { User friendly: } \\
\text { directions and } \\
\text { instructions }\end{array}$ & 16 & 53 & 14 & 47 & 0 & 0 & 0 & 0 & 0 & 0 \\
\hline $\begin{array}{l}\text { Achievement/ } \\
\text { easy to use }\end{array}$ & 4 & 13 & 26 & 87 & 0 & 0 & 0 & 0 & 0 & 0 \\
\hline $\begin{array}{l}\text { Differences in } \\
\text { learning }\end{array}$ & 7 & 23 & 21 & 70 & 2 & 7 & 0 & 0 & 0 & 0 \\
\hline
\end{tabular}

Table 7 showed the result of six teacher responses to the Cerdik BM Series 1 interactive application. All teachers $100 \%(n=6)$ had given a score of 4 for the interface and sound of Cerdik BM Series 1. For the criteria of engagement or motivation, two teachers had given a score of 4 and four teachers had given a score of 3 . The user friendly criteria indicated that all teachers $(n=6)$ or $100 \%$ had given a score of 4 . In addition, $67 \%(n=$ $4)$ teachers had given a score of 3 and $33 \%(n=2)$ had given a score of 4 for the achievement criteria or easy to use. Furthermore, 67\% $(n=4)$ teachers had given a score of 3 and another $33 \%(n=2)$ had given a score of 4 for the difference in learning criteria.

Table 7

Teachers' Feedbacks on the use of Cerdik BM Series 1 Interactive Application

\begin{tabular}{|c|c|c|c|c|c|c|c|c|c|c|}
\hline \multirow{2}{*}{ Criteria/Score } & \multicolumn{2}{|l|}{4} & \multicolumn{2}{|l|}{3} & \multicolumn{2}{|l|}{2} & \multicolumn{2}{|l|}{1} & \multicolumn{2}{|l|}{0} \\
\hline & $f$ & $\%$ & $f$ & $\%$ & $f$ & $\%$ & $f$ & $\%$ & $f$ & $\%$ \\
\hline Interface and sound & 6 & 100 & 0 & 0 & 0 & 0 & 0 & 0 & 0 & 0 \\
\hline $\begin{array}{l}\text { Engagement/ } \\
\text { motivation }\end{array}$ & 2 & 33 & 4 & 67 & 0 & 0 & 0 & 0 & 0 & 0 \\
\hline $\begin{array}{l}\text { User friendly: } \\
\text { directions and } \\
\text { instructions }\end{array}$ & 6 & 100 & 0 & 0 & 0 & 0 & 0 & 0 & 0 & 0 \\
\hline $\begin{array}{l}\text { Achievement/easy } \\
\text { to use }\end{array}$ & 2 & 33 & 4 & 67 & 0 & 0 & 0 & 0 & 0 & 0 \\
\hline $\begin{array}{l}\text { Difference in } \\
\text { learning }\end{array}$ & 2 & 33 & 4 & 67 & 0 & 0 & 0 & 0 & 0 & 0 \\
\hline
\end{tabular}




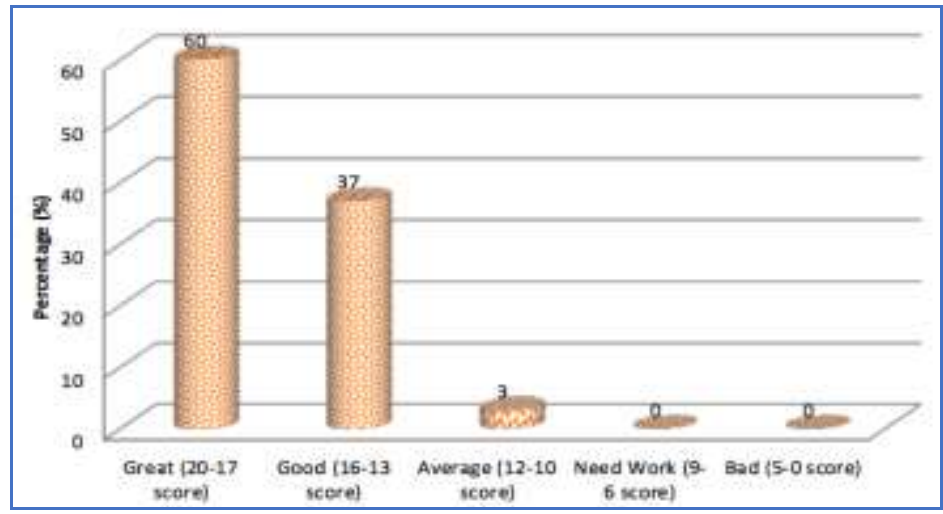

Figure 1

Pupils’ Analysis Score for the Cerdik BM Series 1 Application

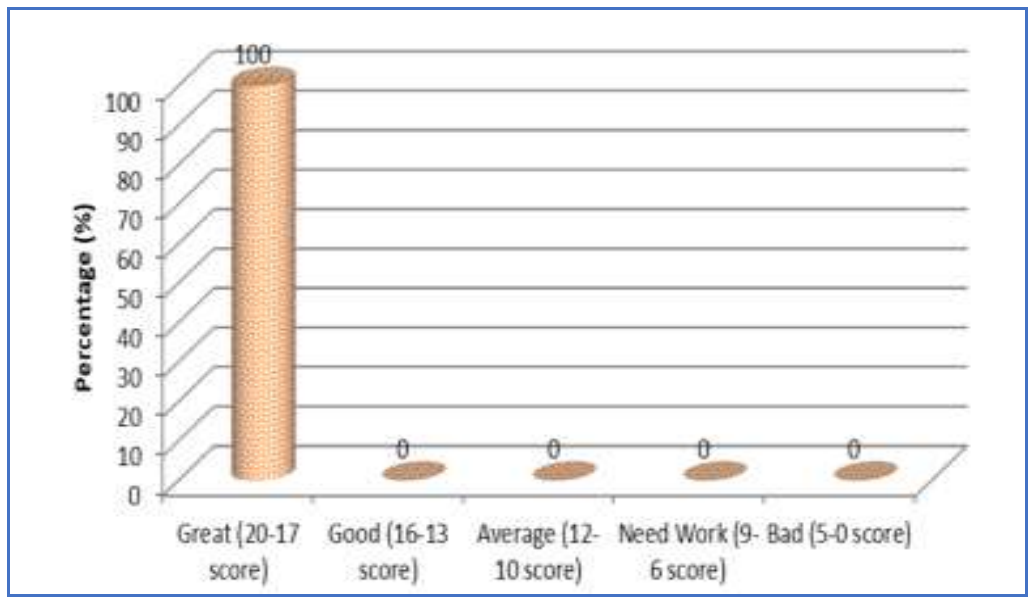

Figure 2

Teachers' Analysis Score of Cerdik BM Series 1 Application

Figure 1 and 2 showed the overall scores that were given by pupils and teachers towards the interactive application of the Cerdik BM Series 1. Based on the graphs, it was notable that most pupils, $60 \%(\mathrm{n}=18)$, had scored well, followed by a good score of $37 \%(\mathrm{n}=11)$ and only one pupil had given a simple score on the Cerdik BM Series 1 . Overall, Figure 2 shows an excellent score for teacher assessment.

\section{Instructional Improvement in Learning Activities for Cerdik BM Series 1}

All the experts had acknowledged that Cerdik BM Series 1 as a good pedagogical tool that could assist LINUS students' reading and writing skills. However, some improvements were recommended in order to make this application more user-friendly. Below were the expert's response extracts $(\mathrm{P})$ : 
"This app is good as a pedagogical tool to help LINUS pupils improve reading and writing skills. But for me it would be better if sentence instructions are summarized so pupils quickly understand what they need to do ". (P1)

"I like the Cerdik BM Series 1 because it works as a learning tool for LINUS pupils. However, instruction on each learning activity can be summarized, compacted and uses words that are more easily understood to fit the child's level of LINUS ". (P3)

"Cerdik BM Series 1 is very good to be introduced to LINUS pupils because it is able to improve pupils' reading and writing skills, but instruction on learning activities can still be improved to make it easier and not too long." (P4)

"Cerdik BM Series 1 is interesting but there is still room for improvements in terms of instructions to the activities displayed". (P5)

Cerdik BM Series 1 Strives to Stimulate Learning and Thinking Skills in LINUS pupils Through Interactive Fun Learning.

The experts also agreed that Cerdik BM Series 1 could stimulate learning and thinking skills through interactive learning. Among the extracts of the interviews expressed by experts were:

"Cerdik BM Series 1 is a pedagogical tool that creates an element of fun learning. The use of learning activities and game-based assessments can indeed stimulate student learning and thinking skills ". (P1)

"I like Cerdik BM Series 1 because it is suitable for LINUS pupils to use in order to stimulate their thinking and learning skills through a fun learning atmosphere". (P2)

"Cerdik BM Series 1 is interesting and can stimulate LINUS pupils' learning. The use of interesting animations and assessment through games can stimulate pupils' thinking skills". (P3)

"Congratulations, the construction of interactive apps like the Cerdik BM Series 1 needs to be continued! Able to stimulate thinking skills through interactive learning". (P4)

"Cerdik BM Series 1 can stimulate reading and writing skills while enjoying". (P5)

"This application has a high potential to attract remedial pupils' involvement in the teaching and learning process". (P6)

Cerdik BM Series 1 is packed with the integration of Pupils' Multiple Intelligences compatible with 21st Century Education Context

All experts had affirmed the parallelism of Cerdik BM Series 1 with the integration of multiple intelligences. The followings were the expert responses:

"Cerdik BM Series 1 is very interesting with a combination of eight different types of intelligence. It fits perfectly with the context of the 21 st century education ". (P1)

"The Curriculum of Cerdik BM Series 1 conforms to eight types of intelligence such as verbal linguistics, mathematical logic, visual spatial, kinestatics, music, interpersonal, 
intrapersonal and naturalist. The combination of eight different intelligences makes this app very eye-catching". (P2)

"The use of multiple intelligences in the Curriculum of the Cerdik BM Series 1 can help weak pupils to have interest in learning". (P5)

"Good! I see there is integration of multiple intelligences in every construct of this application ". (P6)

\section{The Application of the Concept Fun Learning Motivates Pupils to Improve Listening, Speaking, Reading and Writing Skills}

Eight experts credited that the integration of fun learning in Cerdik BM Series 1 would motivate students' achievement in mastering listening, speaking, reading and writing skills. Below were some of their responses.

"This fun learning concept application can motivate LINUS pupils to improve listening, speaking, reading and writing skills". (P1)

"The Cerdik BM Series 1 application attracts and helps LINUS pupils to improve listening, speaking, reading and writing skills through the fun learning concept". (P2)

"The Cerdik BM Series 1 application is interesting and not boring due to the application of the fun learning concept". (P3)

"Integration of fun learning through the application of Cerdik BM Series 1 is able to motivate the achievement in listening, speaking, reading and writing skills among LINUS pupils". (P6)

"The Application of Cerdik BM Series 1 is solid with the element of fun learning that can motivate pupils in improving listening, speaking, reading and writing skills". (P7)

\section{DISCUSSION}

The findings had evidently shown that there was an almost perfect agreement between the experts in the appointed panel on the designs of the information, interaction and presentation.

The first evaluation criteria - the design of the information, the content of the application, the language, the various intelligence elements, the elements of thinking skills, the students' present knowledge on daily life and the interactive concept of interactivity - in the Cerdik BM Series 1 had obtained a definite agreement among the panel of experts. All of these elements were essential in nurturing learning motivation for the students. According to $\mathrm{Li}$ (2016), pedagogical tools used in classroom deliverance must be able to develop students' learning skills, to raise awareness of selflearning and to provide knowledge to students.

All experts had a mutual agreement on the second evaluation criteria - the design of the interaction. The experts agreed that Cerdik BM Series 1 was clear in terms of its content, instructions and navigation representation. In addition, the experts also affirmed that Cerdik BM Series 1 had accurate and easy to handle response provider system. 
Besides being easily accessible, Cerdik BM Series 1 had successfully promoted regulated performance control. It also had easily identifiable representations such as icon buttons and consistent navigation system. The success of the Cerdik BM Series 1 compared to LINUS's previous interactive applications was in terms of technology used. This is stated based on the study of Miswan and Mohd Adnan (2017) that the development of LINUS applications in their study used only iPad technology (touch screen) which was different from the Cerdik BM Series 1 which used computer technology to overcome the constraints of urban and rural students who still had no iPad support school. The technique of dragging, snapping, resizing (when the honer button in a particular text pops up a big picture to attract students) was an added benefit of the Cerdik BM Series 1 in computer use compared to the iPad. In fact, all of the techniques used (dragging, snapping, resizing) in the Cerdik BM Series 1 made it more interactive than just using touch screen techniques. These findings were in line with Khaleel, Ashaari, Wook and Ismail (2016) who highlighted the importance of having a good interaction design that could reflect interactive learning content in order to achieve good learning outcomes. Cerdik BM Series 1- an interactive-based pedagogical tool - not only had some positive impacts on the learning process but it could also facilitate teachers in the classroom.

Apart from that, the panel of experts also had a mutual agreement on the following aspects: graphics, writing, color, audio, video, animation and buttons. These findings were in line with $\mathrm{Li}$ (2016) who had ascertained that multimedia technology could attract students more easily than the chalk \& talk teaching. When students are attracted to multimedia presentations, they would be more motivated to continue learning through these interactive applications (Kennedy, Deshler, Lloyd, 2015; Li, 2016). Hence, this process would gradually increase students' involvement in the learning process $(\mathrm{Li}$, 2016). Moreover, the use of multimedia such as animation could improve students' performance and satisfaction while learning and it could also generate better long-term retention (Chiou, Tien \& Lee, 2015). Chun-hui and Fu (2015) further stated that the integration of sound, image, text, and animation could enhance students' sense of stimulation. In addition, teaching sessions and learning processes could be more effective through the use of clear three-dimensional graphics.

The curriculum of Cerdik BM Series 1 also obtained a high agreement value among the experts. The main aim of the constructive alignment model in the curriculum of Cerdik $\mathrm{BM}$ Series 1 was to promote student-centered learning. Aspects like the learning outcomes (can be done, viewed, measured and assessed), the lesson content (according to the syllabus description) and the learning activities (which were carefully aligned with the application's learning outcomes and assessments) had been thoroughly examined by the panel of experts.

All the experts agreed that Cerdik BM Series 1 contained various types of intelligences (refer to Table 1). All students felt that Cerdik BM Series 1 had motivated them throughout the use of the application. These students also claimed that this application had given them the opportunities to be actively engaged with the learning activities. Based on Andresen and Brink (2013), the integration of multiple intelligences in 
multimedia could inspire, motivate and help students to gain knowledge independently. This finding was also in line with Hanafin's (2014) intelligence projects in Ireland in which the students felt that they were valued when various multiple intelligences were addressed in the classroom. The exposure to various intelligences had prevented these students from being marginalized and also had provided opportunities to showcase students' individual talents and abilities (Hanafin, 2014). The inclusion of multiple intelligences theory is a part of the unique elements compared to the previous LINUS application (Maswan \& Mohd Adnan, 2017). This was also supported by studies that claim that the diversity of LINUS students should also be taken into account when incorporating a fun learning environment in LINUS student learning (Rahman \& Badusah, 2019). The application of multiple intelligences and game based learning was a powerful combination of two theories that was the catalyst for the success of the Cerdik BM Series 1 compared to the previous LINUS student learning applications.

Cerdik BM Series 1 was a good platform for students to "try and retry" the learning activities, and by allowing the students to view their individual scores in its interface, some sense of excitement had been infused in the learning process. According to Rosly, Rahim and Halim (2016), digital learning was not only fun but it could also attract students' especially young learner's interest. Hanafin (2014) explained that learning using computers would make students to be more focused, active and confident. Hence, technology integration should be user-friendly and this was one of the most important aspects that researchers should consider when developing any interactive applications for learning purposes. The teachers' and students' responses on the rubric assessment revealed that all of the respondents agreed that Cerdik BM Series 1 was very easy to use because of its clear instructions and its easy-to-follow voice recordings. This finding evidently supported Shabiralyani, Hasan, Hamad and Iqbal (2015) and Syawaludin, Gunarhadi and Rintayati (2019) who stated that the use of interactive application technology could greatly help to create an encouraging learning environment that could successfully attract students' interest and attention (Alqudah, Bidin \& Hussin, 2019). In addition, teachers' knowledge and design, procedures and links during the classroom teaching session could empower the content of the lessons in the classroom and create user-friendly (Wang, 2018). Besides that, Sabu (2018) stated that the use of multimedia technology could also improve students' high-level thinking skills. The findings of the interviews conducted with the experts also revealed that Cerdik BM Series 1 could stimulate the learning and thinking skills of students in the LINUS program.

\section{CONCLUSION}

This study had successfully answered all its research questions and several conclusions about Cerdik BM Series 1 could be made. Firstly, Cerdik BM Series 1 had achieved high reliability scores in terms of its design and curriculum. Secondly, Cerdik BM Series 1 had high agreement values for its design and curriculum. Thirdly positive students' and teachers' feedbacks had proven that this interactive application was a preferred learning tool. Fourthly, the positive interview findings had undoubtedly justified the use of this application as a pedagogical tool to stimulate the listening, speaking, reading and writing skills among students in the LINUS program. Finally, Cerdik BM Series 1 had successfully promoted fun learning concept by integrating learning activities with 
multiple intelligences, multimedia elements and also game-learning concept. Three implications of this study were (i) majority of the respondents loved and enjoyed this interactive learning tool that combined five multimedia elements, (ii) the respondents also relished its interface concepts namely the fun fair and the water park themes, (iii) the integration of pupils' multiple intelligences for each interface also supported students' motivation to learning. In conclusion, the development of interactive applications based on the 4-D development study method had helped researchers to develop an interactive pedagogical tool that could stimulate the thinking skills, language competency, motivation and confidence of students in the LINUS program.

\section{ACKNOWLEDGEMENT}

The authors would like to thank the Ministry of Education Malaysia and the Dewan Bahasa dan Pustaka in funding this study under the Research and Innovation Provisioning Scheme, Initiative 108 (S / 0 code: 777401) and Research and Innovation Management Center, Universiti Utara Malaysia, Kedah for the administration of this study.

\section{REFERENCES}

Abdul Wahid, P. R., \& Samsudin, N. H. (2017). Reading skills among special remedial children. Proceeding of RF-ISERD International Conference, (pp.1-6). Singapore.

Ajam, A. A., \& Hemmatipoor, O. (2018). The relationship between multiple intelligences and health literacy in healths pupils in Gonabad UMS, 2017. Journal of Community Health Research, 7(1), 48-56.

Alqudah, D., Bidin, A., \& Hussin, M. A. H. (2019). The impact of educational infographic on students' interaction and perception in Jordanian higher education: Experimental study. International Journal of Instruction, 12(4), 669-688.

Andresen, B. B., \& Brink, K. (2013). Multimedia in education: Curriculum. Moscow: UNESCO Institute for Information Technologies in Education.

Chiou, C. C., Tien L. C., \& Lee L. T. (2015). Effects on learning of multimedia animation combined with multidimensional concept maps. Computers \& Education, 80, 211-223.

Chun-hui, Z., \& Fu, L. (2015). The use of multimedia in higher special education. USChina Education Review, 5(8), 568-571.

Creswell, J. W. (2014). Educational research: Planning, conducting and evaluating quantitative and qualitative research. United Kingdom: Pearson Education Limited.

Danakorn, N. (2011). Perisisan multimedia berasaskan animasi bagi pembelajaran sisihan. (Tesis sarjana yang tidak diterbitkan). Universiti Teknologi Malaysia, Johor.

Gunawardhana, L. K., \& Palaniappan, S. (2016). Possibility of using multimedia application for Learning. GSTF Journal on Computing (JoC), 5(1), 77-83. 
Hanafin, J. (2014). Multiple intelligences theory, action research, and teacher professional development: The Irish MI project. Australian Journal of Teacher Education, 39(4). 126-141.

Huizenga, J. C., Dam, G. T. M., Voogt, J. M., \& Admiraal, W. F. (2017). Teacher perceptions of the value of game-based learning in secondary education. Computers \& Education, 110, 105-115.

Kennedy, M. J., Deshler, D. D., \& Lloyd, J. W. (2015). Effects of multimedia vocabulary instruction on adolescents with learning disabilities. Journal of Learning Disabilities, 48(1), $22-38$.

Khaleel, F. L., Ashaari, N. S., Wook, T. S. M. T., \& Ismail, A. (2016). Gamification elements for learning applications. International Journal of Advanced Science of Engineering and Information Technology, 6(6), 868-874.

Landers, R. N. (2019). A step-by-step introduction to statistic for business. London, United Kingdom: Sage Publication Ltd.

Law, V., \& Chen, C. H. (2016). Promoting science learning in game-based learning with question prompt and feedback. Computers and Education, 63(C), 50-58.

Li, W. Y. (2016). Transforming conventional teaching classroom to learner-centred teaching classroom using multimedia-mediated learning module. International Journal of Information and Education Technology, 6(2), 105-112.

Ministry of Education. (2013). LINUS 2.0 Literasi Bahasa Melayu: Modul Murid Asas 1. Kuala Lumpur: Ministry of Education.

Miswan, M., \& Mohd Adnan, H. (2017). Pembangunan Aplikasi Peranti Mudah Alih untuk Kemahiran Membaca Kanak-Kanak: Aplikasi Literasi LINUS (LiLIN). Malaysian Journal of Media Studies, 17(2), 64-78.

Pallant, J. (2001). SPSS survival manual. USA: Open University Press.

Peng, C. F. (2015). Pelaksanaan program literasi dan numerasi (LINUS) di sekolah rendah. Jurnal Pendidikan Bahasa Melayu, 5(2), 1-11.

Rahman, K., \& Badusah, J. (2018). Perkembangan Literasi Bahasa Melayu Melalui Aplikasi Didik Hibur Dalam Kalangan Murid Linus. In Proceeding Transdisciplinary Education Conference (STED 2018). Retrieved from https://sted18.files.wordpress.com/2018/12/1-59-kornia-rahman-jamaludin-badusah.pdf.

Rajendra, I. M., \& Sudana, I. M. (2018). The influence of interactive multimedia technology to enhance achievement pupils on practice skills in mechanical technology. Journal of Physics: Conference Series, 953, 1-5.

Rosly, N. S., Rahim, N. A., \& Halim, H. A. (2016). Interaksi ujaran kanak-kanak menerusi elemen pendigitalan dalam penceritaan. GEMA Online ${ }^{\circledR}$ Journal of Language, 16(1), 89-108. 
Sabu, N. (2018). The effect of using interactive multimedia courseware with pedagogical agent in learning nutrition towards higher order thinking skills. International Journal of Academic Research in Business and Social Sciences, 8(2), 623-635.

Salleh, N. M., Ghazali, K., \& Nor, M. M. (2017). Penceritaan digital dalam pemerolehan leksikal Bahasa Jepun. GEMA Online Journal of Language Studies. 17(1), $55-75$.

Schrock, K. (2018). Critical evaluation of mobile apps. Retrieved from http://www.ipads4teaching.net/critical-eval-of-apps.html

Selvarajan, P., \& Vasanthagumar, T. (2012). The impact of remedial teaching on improving the competencies of low achievers. International Journal of Social Science and Interdisciplinary Research, 1(9), 49-58.

Shabiralyani, G., Hasan, K. S., Hamad, N., \& Iqbal, N. (2015). Impact of visual aids in enhancing the learning process case research: District Dera Ghazi Khan. Journal of Education and Practice, 6(19), 226-233.

Syawaludin, A., Gunarhadi, \& Rintayati, P. (2019). Development of augmented realitybased interactive multimedia to improve critical thinking skills in science learning. International Journal of Instruction, 12(4), 331-344.

Udosen, A. E., Udofia, N., Ekukinam, T., \& Akpan, L. P. (2010). Empowering primary schools pupils through literacy remediation project in Uyo Local Government Area. African Research Review, 4(3b), 55-70.

UNICEF. (2018). Learning through play: Strengthening learning through play in early childhood education programmes. New York: UNICEF Education Section.

United Nations. (2019). Sustainable development goals: 4 quality education. Retrieved from https://www.un.org/sustainabledevelopment/education/.

Wang, L. (2018). A study of pupils' English cooperative learning strategy in the multimedia environment. Theory and Practice in Language Studies, 8(6), 601-605.

Wiana, W. (2018). The effectiveness of using interactive multimedia in improving the concept of fashion design and its application in the making of digital fashion design. IOP Conference Series: Materials Science and Engineering, 306, 21-31.

Williams, R. B. (2007). Multiple intelligences for differentiated learning. United States of America: Corwin Press. 